\title{
Сучасний підхід до лікування хворих із тромбозом глибоких вен нижніх кінцівок
}

\author{
С.М. Василюк, В.М. Атаманюк
}

Івано-Франківський національний медичний університет, Івано-Франківськ

\section{Реферат}

Проведено аналіз діагностики та лікування 98 хворих із тромбозом глибоких вен нижніх кінцівок. Залежно від застосованої схеми антикоагулянтної терапії пацієнти були поділені на три групи: перша група - 32 хворих, які отримували варфарин, друга група 34 - ривароксабан, третя 32 - дабігатрану етексилат. Усім пацієнтам 3 метою верифікації діагнозу і моніторингу якості терапії проводили ультрасонографічне дослідження, оцінювали тромбогенні властивості периферичної крові (ступінь, час, швидкість агрегації, фактор Віллебранда), загортальну та протизгортальну систему крові (антитромбін, протеїн C, рівень Д-димеру). Для оцінювання якості життя хворих використовували спеціалізований опитувальник CIVIQ-1. Застосовували шкалу Villalta для встановлення як ймовірного діагнозу, так і ступеня тяжкості ПТС. На підставі оцінки результатів дослідження зроблено висновок, що лікування хворих із тромбозом глибоких вен потребує індивідуалізованих підходів до визначення схеми та термінів антикоагулянтної терапії.

Ключові слова: тромбоз глибоких вен, антикоагулянтна терапія, діагностика.

The update approach to treatment of deep vein thrombosis

S.M. Vasyliuk, V.M. Atamaniuk

Ivano-Frankivsk National Medical University

Abstract
An analysis of the diagnosis and treatment of 98 patients with deep vein thrombosis was performed.Depending on the scheme of anticoagulant therapy, patients were divided into three groups: the first group 32 - received warfarin, the second group 34 - rivaroxaban, and the third 32 - dabigatran etexilate. All patients to verify the diagnosis and monitoring of a therapy performed ultrasonographic study evaluated thrombogenic properties of peripheral blood (level, time, speed aggregation, von Willebrand factor) coagulation and anticoagulant blood system (antithrombin, protein C, the level of D-dimer). A specialized CIVIQ-1 questionnaire was used to assess patients' quality of life. The Villalta scale was used to establish both the diagnosis and severity of PTS.Based on the results of the study, it is concluded that the treatment of patients with deep vein thrombosis requires individualized approachesto defining the scheme and timing of anticoagulation therapy.

Key words: deep vein thrombosis, anticoagulation therapy, diagnosis.

Вступ. Згідно 3 наявними на сьогодні тактичними підходами до лікування тромбозу глибоких вен (ТГВ), основними завданнями є: запобігти прогресуванню тромбозу, не допустити розвитку венозної гангрени, зберегти функцію венозних клапанів (попередити розвиток посттромботичного синдрому (ПТС)), профілактика рецидиву ТГВ, попередити ТЕЛА та летальний наслідок [1]. При аналізі даних багатоцентрових рандомізованих досліджень, присвячених лікуванню і профілактиці ТГВ, можна відзначити, що у світовій практиці переважає консервативний підхід до терапії ТГВ. Однак існують дискутабельні питання, пов'язані 3 вибором оптимального препарату та тривалості антикоагулянтної терапії, термінів початку динамічного навантаження на кінцівку та використання компресійної терапії [2].

Основні діагностично-лікувальні підходи у хворих на гострий тромбоз глибоких вен нижніх кінцівок на сьогодні базуються на рекомендаціях American College of Chest Physicians EvidencedBased Clinical Practice Guidelines 2016, які передбачають застосування антикоагулянтів, як патогенетично обгрунтованих препаратів [3]. Антикоагулянтна терапія призначається в той же день, коли був встановлений діагноз. Вибір антикоагулянта повинен враховувати такі медичні питання, як ефективність, безпека, прийом інших медичних препаратів одночасно та супутні захворювання, які супроводжуються порушенням функції нирок та печінки. Крім того, слід враховувати такі практичні питання, як доступність препарату, вартість та вибір пацієнта [4].

В останні 50 років лікування ТГВ базувалося на застосуванні низькомолекулярних гепаринів та антагоністу вітаміну К. Через недоліки підшкірного введення гепаринів та притаманних їм обмежень і широкого терапевтичного вікна варфарину, були розроблені та запроваджені у клінічну практику новітні оральні антикоагулянти (НОАК) [5].

Систематизація і напрацювання єдиних патогенетично обгрунтованих діагностично-лікувальних підходів до терапії пацієнтів з тромбозом глибоких вен нижніх кінцівок $\epsilon$ актуальною проблемою судинної хірургії.

Мета дослідження: покращити результати хірургічного лікування гострого тромбозу глибоких вен нижніх кінцівок та профілактику рецидиву й ускладнень, шляхом обгрунтування вибору та тривалості антикоагулянтної терапії на основі оцінки клінічних, лабораторних та інструментальних показників.

Матеріали та методи. Нами піддано комплексному обстеженню та лікуванню 98 хворих на ТГВ 
нижніх кінцівок різної локалізації. Серед обстежених хворих було $56(57,1 \%)$ чоловіків і $42(42,9 \%)$ жінки. Більшість пацієнтів (54,3\%) були працездатного віку. У 60 (61,2\%) хворих тромбоз глибоких вен розцінювали як спровокований: у 10 з них впродовж останнього місяця були оперативні втручання на органах черевної порожнини, у 15 операції 3 приводу складних переломів кісток гомілки та у 13 - травми стегнової кістки та кісток тазу, 22 пацієнти мали інші тимчасові не хірургічні фактори, що спричинили тромбоз нижніх кінцівок. Найбільша кількість хворих госпіталізовані в терміни від 4-7 діб від початку захворювання. Тромбоз глибоких вен правої нижньої кінцівки діагностували у 39 (39,8\%) паціснтів, лівої - у 59 $(60,2 \%)$. Дистальний тромбоз глибоких вен був у $24(24,5 \%)$ хворих, поєднання тромбозу литкових і підколінної вени - у 4 (8,5\%) та проксимальний - у $70(67,0 \%)$. Загальна характеристика пацієнтів наведена в таблиці 1.

Пацієнти були поділені на три дослідні групи в залежності від особливостей антикоагулянтної терапії ТГВ. Першу групу склали 32 пацієнти, у яких впродовж перших 5 діб вводили еноксапарин в дозі 0,1 мл на 10 кг маси тіла хворого двічі на добу, з одночасним призначенням варфарину в дозі 5 мг з наступною корекцією цієї дози згідно 3 показником МНВ. Низькомолекулярні гепарини відміняли, коли даний показник досягав терапевтичного рівня гіперкоагуляції (дорівнював або перевищував 2). Середні терміни підбору дози варфарину складали $6,3 \pm 0,8$ доби. Тридцять чоти- ри пацієнти сформували другу дослідну групу. У них застосовували ривароксабан у дозі 15 мг двічі на добу перорально впродовж перших трьох тижнів, далі по 20 мг на добу продовжували не менше трьох місяців лікування. До третьої дослідної групи ввійшло 32 пацієнти, в яких лікування ТГВ проводили введенням НМГ у дозі 0,1 мл на 10 кг маси тіла хворого двічі на добу впродовж 5 діб, а 3 шостої доби пацієнтам призначали дабігатрану етексилат у дозі 150 мг перорально двічі в добу.

У цьому дослідженні всі пацієнти надали підписану інформовану згоду.

Антикоагулянтна терапія у всіх групах хворих проводилась впродовж не менше 3 місяців не залежно від рівня тромбозу.

Усім пацієнтам проводили загальноклінічні лабораторні обстеження 3 визначенням показників кількості тромбоцитів, еритроцитів, гемоглобіну, лейкоцитів, визначали основні показники коагулограми (протромбіновий час, протромбіновий індекс, активований частковий тромбопластиновий час, міжнародне нормалізоване відношення, фібриноген, гематокрит). Оцінювали тромбогенні властивості периферичної крові (ступінь, час, швидкість агрегації, фактор Віллебранда), загортальну та протизгортальну систему крові (антитромбін III, протеїн С, рівень Д-димеру). Для оцінювання якості життя хворих використовували спеціалізований опитувальник CIVIQ-1. Застосовували шкалу Villalta для встановлення як діагнозу, так i ступеня тяжкості ПТС.

Загальна характеристика пацієнтів з ТГВ

Таблиця 1

\begin{tabular}{|c|c|c|}
\hline Характеристики & $\begin{array}{c}\text { Період початкової та } \\
\text { тривалої антикоагуляції } \\
\text { (3-6 міс) }\end{array}$ & $\begin{array}{c}\text { Розширений період } \\
\text { спостереження } \\
\text { (7-120 міс) }\end{array}$ \\
\hline Вік (медіана) & $68,7(48,0)$ & $58,2(46,0)$ \\
\hline Чоловіча стать & $56(57,1 \pm 5,0 \%)$ & $39(51,3 \pm 5,7 \%)$ \\
\hline Тривалість терапії 3 місяці & $24(24,5 \pm 4,3 \%)$ & $20(26,3 \pm 5,0 \%)$ \\
\hline Тривалість терапії 6 місяців & $55(56,1 \pm 5,0 \%)$ & $39(51,3 \pm 5,7 \%)$ \\
\hline Тривалість терапії >6 місяців & $19(19,4 \pm 3,9 \%)$ & $17(22,4 \pm 4,8 \%)$ \\
\hline \multicolumn{3}{|c|}{ Провокуючі тимчасові фактори ризику } \\
\hline Хірургічні втручання & $10(10,2 \pm 3,0 \%)$ & $7(9,2 \pm 3,3 \%)$ \\
\hline $\begin{array}{l}\text { Нехірургічні минаючі фактори } \\
\text { ризику }\end{array}$ & $24(24,5 \pm 4,3 \%)$ & $19(25,0 \pm 4,9 \%)$ \\
\hline Тривалі подорожі & $5(5,1 \pm 2,2 \%)$ & $3(3,9 \pm 2,2 \%)$ \\
\hline Іммобілізація & $28(28,6 \pm 4,6 \%)$ & $19(25,0 \pm 4,9 \%)$ \\
\hline Запальні захворювання & $36(36,7 \pm 4,8 \%)$ & $29(38,2 \pm 5,5 \%)$ \\
\hline $\begin{array}{l}\text { Застосування КОК на момент } \\
\text { тромбозу }\end{array}$ & $9(9,2 \pm 2,92 \%)$ & $6(7,9 \pm 3,0 \%)$ \\
\hline
\end{tabular}




\begin{tabular}{|l|c|c|}
\hline \multicolumn{3}{|c|}{ Провокуючі стійкі фактори ризику } \\
\hline Активний рак & $8(8,2 \pm 2,8 \%)$ & $2(2,6 \pm 1,8 \%)$ \\
\hline Тромбоз в анамнезі & $21(21,4 \pm 4,1 \%)$ & $18(23,7 \pm 4,8 \%)$ \\
\hline Серцево-судинні захворювання & $39(39,8 \pm 4,9 \%)$ & $22(28,9 \pm 5,2 \%)$ \\
\hline Серцева недостатність & $5(5,1 \pm 2,2 \%)$ & $4(5,3 \pm 2,5 \%)$ \\
\hline Діагностована тромбофілія & $7(7,1 \pm 2,6 \%)$ & $6(7,9 \pm 3,1 \%)$ \\
\hline Варикозна хвороба н/к & $4(4,1 \pm 2,0 \%)$ & $4(5,3 \pm 2,6 \%)$ \\
\hline Паління & $28(28,6 \pm 4,6 \%)$ & $21(27,6 \pm 5,1 \%)$ \\
\hline Спадковий анамнез & $14(14,3 \pm 3,5 \%)$ & $11(14,5 \pm 4,0 \%)$ \\
\hline Непровокуючі фактори & $38(38,8 \pm 4,9 \%)$ & $30(39,5 \pm 5,6 \%)$ \\
\hline Підвищені значення шкали Villalta & $16(16,3 \pm 3,7 \%)$ & $9(11,8 \pm 3,7 \%)$ \\
\hline Підвищений рівень D-димеру & $93(94,9 \pm 2,2 \%)$ & $21(27,6 \pm 5,1 \%)$ \\
\hline
\end{tabular}

У всіх випадках підозри на тромбоз глибоких вен нижніх кінцівок проводили триетапне сонографічне дослідження: компресію глибоких вен, двовимірне сканування та кольорове дуплексне картування.
Результати досліджень та їх обговорення. При наявності клінічних ознак проксимального чи дистального ТГВ проводили оцінку ймовірності ТГВ згідно з рекомендаціями Wells та співавторів (таблиця 2) [6].

Частота ознак ТГВ згідно з Wells у обстежених хворих

Таблиця 2

\begin{tabular}{|c|c|c|c|c|}
\hline \multirow{2}{*}{ Показник } & \multicolumn{2}{|c|}{$\begin{array}{l}\text { Спровокований ТГВ } \\
(\mathrm{n}=60)\end{array}$} & \multicolumn{2}{|c|}{$\begin{array}{l}\text { Не спровокований ТГВ } \\
(\mathrm{n}=38)\end{array}$} \\
\hline & $\begin{array}{l}\text { прокси- } \\
\text { мальний }\end{array}$ & $\begin{array}{l}\text { дисталь- } \\
\text { ний }\end{array}$ & $\begin{array}{l}\text { Прокси- } \\
\text { мальний }\end{array}$ & $\begin{array}{l}\text { дисталь- } \\
\text { ний }\end{array}$ \\
\hline $\begin{array}{l}\text { Активний рак (у даний час або попередні } 6 \\
\text { місяців) }\end{array}$ & $\begin{array}{c}6 \\
(10 \%)\end{array}$ & $\begin{array}{c}2 \\
(3,3 \%)\end{array}$ & $\begin{array}{c}0 \\
(0 \%)\end{array}$ & $\begin{array}{c}0 \\
(0 \%)\end{array}$ \\
\hline $\begin{array}{l}\text { Плегія, глибокий парез, чи недавня іммобілізація } \\
\text { нижньої кінцівки }\end{array}$ & $\begin{array}{l}2 \\
(3,3 \%)\end{array}$ & $\begin{array}{c}5 \\
(8,3 \%)\end{array}$ & $\begin{array}{c}0 \\
(0 \%)\end{array}$ & $\begin{array}{c}0 \\
(0 \%)\end{array}$ \\
\hline $\begin{array}{l}\text { Ліжковий режим більше } 3 \text { днів чи велика операція } \\
\text { в попередні } 4 \text { місяці }\end{array}$ & $14(23,3 \%)$ & $15(25,0 \%)$ & $0(0 \%)$ & $0(0 \%)$ \\
\hline Болючість при пальпації за ходом глибоких вен & $17(28,3 \%)$ & $23(38,3 \%)$ & $14(36,8 \%)$ & $\begin{array}{c}11 \\
(28,9 \%)\end{array}$ \\
\hline Набряк усієї кінцівки & $19(31,7 \%)$ & $26(43.3 \%)$ & $\begin{array}{c}8 \\
(21,0 \%)\end{array}$ & $\begin{array}{c}17 \\
(44,7 \%)\end{array}$ \\
\hline Набряк хворої литки більше, ніж на 3 см & $\begin{array}{c}9 \\
(15,0 \%)\end{array}$ & $\begin{array}{c}6 \\
(10,0 \%)\end{array}$ & $\begin{array}{c}8 \\
(21,0 \%)\end{array}$ & $\begin{array}{c}7 \\
(18,4 \%)\end{array}$ \\
\hline «Симптом ямки» при пальпації ураженої кінцівки & $38(63,3 \%)$ & $17(28,3 \%)$ & $12(31,6 \%)$ & $\begin{array}{c}13 \\
(34,2 \%)\end{array}$ \\
\hline $\begin{array}{l}\text { Розширені колатеральні підшкірних вен (не вари- } \\
\text { коз) }\end{array}$ & $27(45,0 \%)$ & $13(21,7 \%)$ & $11(28,9 \%)$ & $\begin{array}{c}9 \\
(23,7 \%)\end{array}$ \\
\hline ТГВ або ТЕЛА в анамнезі & $\begin{array}{c}2 \\
(3,3 \%)\end{array}$ & $\begin{array}{c}1 \\
(1,7 \%)\end{array}$ & $13(34,2,0 \%)$ & $5(13,6 \%)$ \\
\hline
\end{tabular}


При підрахунку балів, згідно з рекомендаціями авторів, нами було встановлено таке. У 28,7\% пацієнтів спостерігалося від 6 до 9 балів, що вказувало на високу ймовірність діагнозу тромбозу глибоких вен. Від 3 до 5 балів, що також вказувало на високу ймовірність діагнозу, ми простежували у $45,7 \%$ хворих. Переважну більшість цих хворих складали пацієнти зі спровокованим проксимальним ТГВ.

При аналізі ймовірності нами було встановлено, що найбільш часто траплялися такі показники: «симптом ямки» при пальпації ураженої кінцівки $80(81,6 \%)$ випадків та набряк усієї кінцівки - 70 $(71,4 \%)$.

Найбільш поширеною скаргою хворих було відчуття розпирання у нижній кінцівці - у 94,7\% випадків. Болючість при стисканні литкового м'яза відзначали у 94,7\% хворих, причому у $100 \%$ випадків - у хворих із індукованим проксимальним тромбозом глибоких вен.

У досягненні позитивного ефекту від консервативної терапії тромбозу і мінімалізації проявів посттромботичного синдрому мала значення ультрасонографічна оцінка давності тромбу.

При проведенні ультрасонографічного моніторингу ефективності консервативної терапії нами була встановлена залежність регресії патологічних змін від давності ТГВ. Зменшення діаметра вени на 10 добу виявлено у 52,6 \% хворих на гострий ТГВ, у $32,0 \%$ - на підгострий ТГВ та $12,5 \%$ - на хронічний ТГВ. На 60 добу ці показники складали $81,2 \%, 72,8 \%$ та 50,0 \% відповідно. У 94,7 \% пацієнтів з гострим ТГВ простежувалося зменшення діаметра вени через 90 діб. Зменшення тромбу в діаметрі у хворих з гострим ТГВ через 30 діб спостерігалося у 35,1 \% випадків, тоді як при підгострому - у 13,8 \%, а при хронічному - у $12,5 \%$. Навіть через 60 діб у хворих 3 хронічним ТГВ відмічали зменшення тромбу тільки - у 25,0 \% випадків. Аналогічні результати були отримані при оцінці протяжності тромбу у вені. Якщо через 60 діб у хворих із гострим ТГВ достовірне зменшення було у 68,7 \% випадків, то у пацієнтів з підгострим - у $59,1 \%$, а 3 хронічним - у 33,3\% (табл. 3).

Наявність залишкового венозного тромбу або ступінь реканалізації визначали 4-ступеневою градацією: оклюзія - відсутність кровотоку у вені, слабка - при компресії ультразвуковим датчиком просвіт вени стискається не більше ніж на $30 \%$, середня - просвіт вени стискається не більше ніж на $50 \%$, добра - вена стискається більше ніж на $70 \%$.

Таблиця 3

Ультрасонографічні критерії ефективності лікування залежно від терміну давності ТГВ

\begin{tabular}{|c|c|c|c|c|c|c|}
\hline \multirow{2}{*}{ Ознака } & \multirow[t]{2}{*}{ Термін ТГВ } & \multicolumn{5}{|c|}{ Терміни моніторингу } \\
\hline & & 5 доба & 10 доба & 30 доба & 60 доба & 90 доба \\
\hline \multirow{3}{*}{$\begin{array}{l}\text { Зменшення діаметра } \\
\text { вени }\end{array}$} & до 3 діб & $35,1 \%$ & $52,6 \%$ & $64,9 \%$ & $81,2 \%$ & $94,7 \%$ \\
\hline & до 14 діб & $13,8 \%$ & $32,0 \%$ & $51,2 \%$ & $72,8 \%$ & н/д \\
\hline & $>4$ діб & 0 & $12,5 \%$ & $50,0 \%$ & $50,0 \%$ & н/д \\
\hline \multirow{3}{*}{$\begin{array}{l}\text { Зменшення тромба в } \\
\text { діаметрі }\end{array}$} & до 3 діб & $17,5 \%$ & $31,6 \%$ & $35,1 \%$ & $61,2 \%$ & $92,3 \%$ \\
\hline & до 14 діб & $6,8 \%$ & $10,3 \%$ & $13,8 \%$ & $36,4 \%$ & н/д \\
\hline & >4 діб & 0 & 0 & $12,5 \%$ & $25,0 \%$ & н/д \\
\hline \multirow{3}{*}{$\begin{array}{l}\text { Зменшення тромба за } \\
\text { протяжністю в вені }\end{array}$} & до 3 діб & $17,5 \%$ & $28,1 \%$ & $35,1 \%$ & $68,7 \%$ & $92,3 \%$ \\
\hline & до 14 діб & 0 & $3,4 \%$ & $24,1 \%$ & $59,1 \%$ & н/д \\
\hline & >14 діб & 0 & 0 & $12,5 \%$ & $33,3 \%$ & н/д \\
\hline \multirow{3}{*}{$\begin{array}{l}\text { Колатеральний ве- } \\
\text { нозний кровотік }\end{array}$} & до 3 діб & - & - & + & + & + \\
\hline & до 14 діб & - & + & + & + & н/д \\
\hline & $>14$ діб & + & + & + & + & н/д \\
\hline
\end{tabular}

Встановлено, що через 30 днів лікування антикоагулянтами кількість пацієнтів, в яких зберігалася оклюзія венозного русла, а також значення показників зі слабким та середнім ступенем река- налізації в трьох дослідних групах статистично значимо не відрізнялися. Через 3 місяці на фоні адекватного лікування добрі результати були досягнуті у другій групі: у жодного пацієнта не 
діагностовано повної оклюзії, кількість пацієнтів із середнім ступенем реканалізації була максимальною. Добра реканалізація на даному етапі спостерігалась у 24 (75\%) пацієнтів 3 групи.

Через 6 місяців та один рік на фоні антикоагулянтної терапії відсоток оклюзії у першій групі був значно вищим ніж у другій і третій групах $(\mathrm{p}<0,05)$. Потрібно відзначити що у другій та третій групах не було пацієнтів 3 оклюзією чи слабкою реканалізацією, відсоток хворих з доброю реканалізацією у другій групі був максимальним $(\mathrm{p}<0,05)$.

Підвищення вмісту Д-димеру >500 нг/мл на час поступлення у стаціонар нами було встановлене у всіх пацієнтів незалежно від термінів початку тромбування. Однак у хворих 3 неорганізованими тромбами їхній рівень достовірно $(\mathrm{p}<0,05)$ перевищував показники контрольної групи у 4,4 разу, а у пацієнтів $з$ давністю тромбозу більше одного тижня - у 2,5. Д-димер на 10 добу лікування знижувався у всіх хворих, однак залишався підвищеним відносно норми.

У всіх обстежених пацієнтів на час поступлення в стаціонар відмічалися ознаки гіперагрерації тромбоцитів (рис.1). Ступінь агрегації виявлено достовірно $(\mathrm{p}<0,05)$ підвищеним $(123,20 \pm 2,75)$ відносно показників контрольної групи $(73,10 \pm 2,81)$.

На 10 добу лікування виявлялися ознаки пригнічення I фаза агрегації тромбоцитів: знижувався ступінь агрегації $(13,35 \pm 6,39 \%)$, подовжувався час

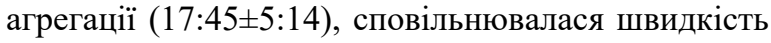
$(13,23 \pm 9,77 \% /$ хв), знижувався вміст фактора Віллебранда $(77,50 \pm 3,70 \%)$. Такі зміни показників агрегатограми, ймовірно, були пов'язані з ефектом від антикоагулянтної терапії i достовірно не відрізнялись у досліджуваних групах хворих.

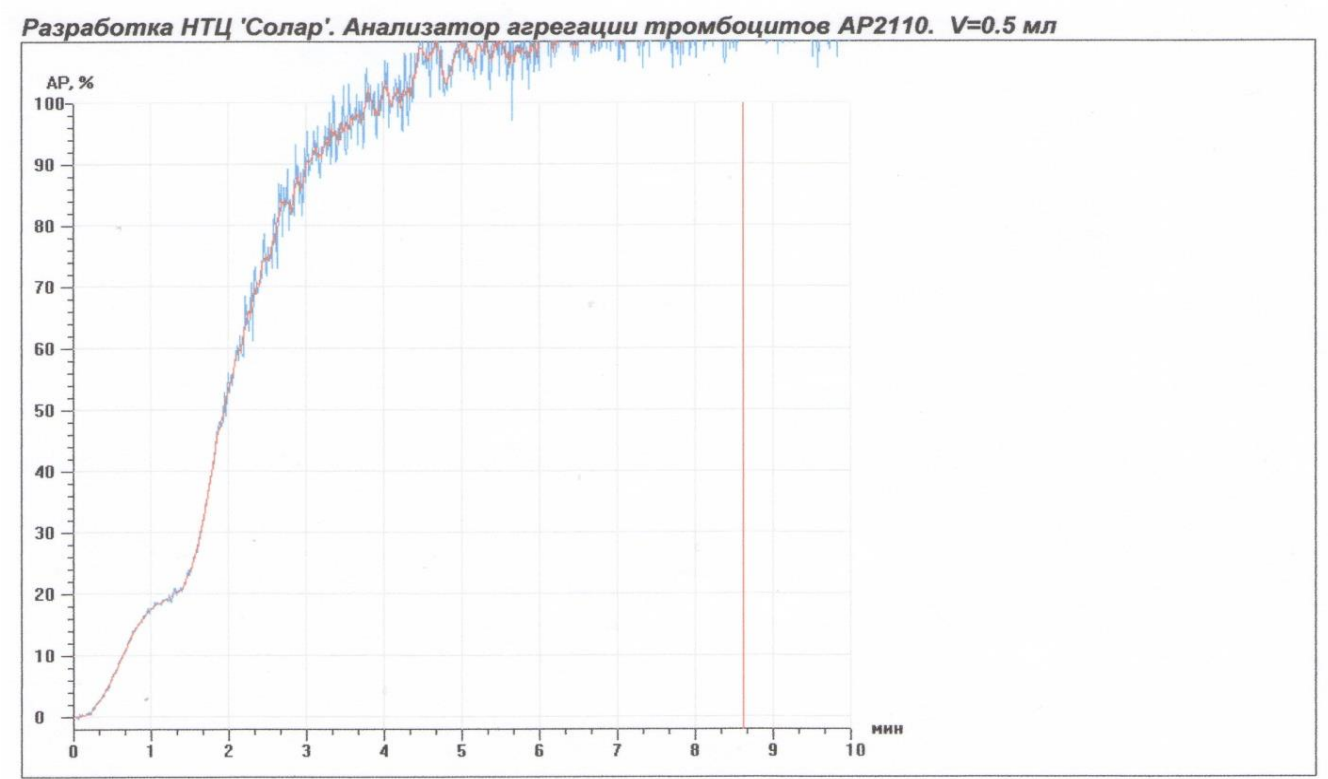

Рис. 1. Ознаки вираженої гіперагрегації (перша доба лікування). Агрегатограма хв. Н, карта стац. хворого

№ 1235. Діагноз: Гострий тромбоз глибоких вен лівої нижньої кінцівки, ілеофеморальний сегмент.

Оцінку якості життя пролікованих хворих проводили у два етапи: при виписці зі стаціонару та на час закінчення прийому антикоагулянтів в амбулаторних умовах. У пацієнтів усіх груп на час виписки зі стаціонару показники суб'єктивної оцінки якості життя достовірно не відрізнялись, проте після закінчення курсу консервативної терапії кращі результати опитування були у хворих другої та третьої груп. Прояви симптомів хронічної венозної недостатності, яка $є$ частим наслідком перенесеного ТГВ, у хворих другої та третьої груп були менш вираженими у порівнянні з пацієнтами першої групи, спосіб життя і праці, яке вони проводили до появи захворювання, змінювався не значно.

Висновки. 1. Лікування хворих із тромбозом глибоких вен потребує індивідуалізованих підходів до визначення схем і термінів антикоагулянтної терапії.
2. При аналізі частоти основних ознак ТГВ, згідно зі шкалою Wells, вірогідно $(\mathrm{p}<0,001)$ трапляються набряк усієї кінцівки, набряк хворої литки більше ніж на 3 см та симптом ямки при пальпації ураженої кінцівки, а ліжковий режим понад три доби чи велика операція в попередні 4 місяці $\epsilon$ недостовірною ( $>0,05)$ ознакою.

3. Оцінка стану судинно-тромбоцитарної ланки системи гемостазу на основі використання тесту 3 АДФ-індукованою агрегацією тромбоцитів свідчить про наявність помірної або вираженої гіперагрегації у всіх обстежених пацієнтів на час поступлення в стаціонар.

4. Об'єктивна оцінка динаміки якості життя після проведеного лікування хворих із ТГВ показала кращі результати у хворих другої та третьої груп, що приймали НОАК, порівняно з першою групою де було призначено НМГ та АВК. 
Інформація про конфлікт інтересів. Автори заявляють про відсутність конфлікту інтересів при виконанні наукового дослідження та підготовці даної статті.

Інформація про фінансування. Автори гарантують, що вони не отримували жодних винагород в будь-якій формі, здатних вплинути на результати роботи.

Особистий внесок кожного автора у виконання роботи:

Василюк С.М. - розробка концепції і дизайну дослідження, аналіз отриманих даних, редагування, статистична обробка даних;

Атаманюк В.М. - збір матеріалу дослідження, розробка дизайну дослідження, аналіз отриманих даних, підготовка тексту статті.

\section{Список використаної літератури}

1. Jeraj L, Jezovnik MK, Poredos P (2017) Rivaroxaban versus warfarin in the prevention of postthrombotic syndrome. Thromb Res 157:46-48.

2. Prandoni P, Ageno W, Mumoli M et al (2017) Recanalization rate in patients with proximal vein thrombosis treated with the direct oral anticoagulants. Thromb Res 153:97-100.

3. Kearon C, Akl EA, Ornelas J, Blaivas A, Jimenez D, Bounameaux H, et al. Antithrombotic therapy for VTE disease: CHEST Guideline and Expert Panel Report. Chest. 2016;149:315-52.

4. Kearon C, Ageno W, Cannegieter SC, Cosmi B, Geersing GJ, Kyrle PA, et al. Categorization of patients as having provoked or unprovoked venous thromboembolism: Guidance from the SSC of ISTH. J Thromb Haemost. 2016;14:1480-3.

5. Young AM. Marshall A. Thirlwall J. Chapman O. Lokare A. Hill C. et al. Comparison of an oral factor Xa inhibitor with low molecular weight heparin in patients with cancer with venous thromboembolism: results of a randomized trial (SELECT-D). J Clin Oncol. 2018;36:2017-23.

6. Wells PS, Ginsberg JS, Anderson DR, Kearon C, Gent M, Turpie AG, Bormanis J, Weitz J, Chamberlain M, Bowie D, et al. Use of a clinical model for safe management of patients with suspected pulmonary embolism. Ann Intern Med. 1998;129:997-1005. doi: 10.7326/0003-4819-129-12-199812150-00002.

Стаття надійшла до редакції: 3.02.2020 p. 